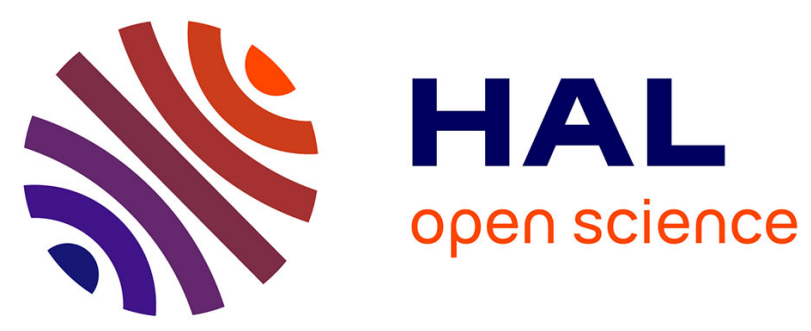

\title{
Contamination sources of PCDD/Fs, non-ortho PCBs and PAHs in sediments of high and low impacted transboundary rivers (Belgium-France)
}

Hermes Sanctorum, Marc Elskens, Martine Leermakers, Yue Gao, Adeline Charriau, Gabriel Billon, Séverine Goscinny, Ward de Cooman, Willy Baeyens

\section{To cite this version:}

Hermes Sanctorum, Marc Elskens, Martine Leermakers, Yue Gao, Adeline Charriau, et al.. Contamination sources of PCDD/Fs, non-ortho PCBs and PAHs in sediments of high and low impacted transboundary rivers (Belgium-France). Chemosphere, 2011, 85 (2), pp.203-209. 10.1016/j.chemosphere.2011.06.031 . hal-00922202

\section{HAL Id: hal-00922202 https://hal.science/hal-00922202}

Submitted on 24 Dec 2013

HAL is a multi-disciplinary open access archive for the deposit and dissemination of scientific research documents, whether they are published or not. The documents may come from teaching and research institutions in France or abroad, or from public or private research centers.
L'archive ouverte pluridisciplinaire $\mathbf{H A L}$, est destinée au dépôt et à la diffusion de documents scientifiques de niveau recherche, publiés ou non, émanant des établissements d'enseignement et de recherche français ou étrangers, des laboratoires publics ou privés. 


\section{Contamination sources of PCDD/Fs, dioxin-like PCBs, PAHs and trace metals in sediments of high and low impacted transboundary rivers (Belgium-France).}

Hermes Sanctorum ${ }^{1}$, Marc Elskens ${ }^{1}$, Martine Leermakers ${ }^{1}$, Yue Gao ${ }^{1}$, Adeline Charriau ${ }^{2}$, Gabriel Billon $^{2}$, Séverine Goscinny ${ }^{3}$, Ward De Cooman ${ }^{4}$, Willy Baeyens ${ }^{1}$

${ }^{1}$ Analytical and Environmental Chemistry, Vrije Universiteit Brussel (VUB), Pleinlaan 2, 1050 Brussels, Belgium.

${ }^{2}$ Université Lille 1 Sciences et Technologies, Laboratoire Géosystèmes (FRE-CNRS 3298), Equipe Chimie Analytique et Marine, 59655 Villeneuve d'Ascq, France.

${ }^{3}$ Department of Pharmaco-bromatology, Scientific Institute of Public Health, J. Wytsmanstraat 14, 1050 Brussels, Belgium.

${ }^{4}$ Flemish Environment Agency (VMM), Alfons Van De Maelestraat 96, 9320 Erembodegem, Belgium.

\footnotetext{
ABSTRACT

Polycyclic aromatic hydrocarbons (PAHs), dioxins (PCDD/Fs and dioxin-like PCBs) and trace metals have been assessed in sediment samples from the Yser and the Upper-Scheldt rivers. The contamination level in the sediments of the Upper-Scheldt river are generally much higher than in the Yser, but a good correlation between all contaminants is observed.

Using several diagnostic PAH ratios, it appears that the PAH levels in the sediments are clearly from pyrolytic (combustion) origin. For the PCDD/Fs and dioxin-like PCBs we compared the fingerprint observed in the sediments with that found in deposition material. In both type of samples the OCDD followed by HpCDD are the dominant congeners for the PCDD/Fs and dioxinlike PCBs. This means that the sources are either combustion and/or atmospheric OCDD formation reactions from pentachlorophenol. The main sources for the high trace metals levels in the sediments of the Upper-Scheldt river are/were steel and non-ferrous metals' smelters, while in Yser river sediments $\mathrm{Cu}$ levels are enhanced due to the natural levels in the soils of that Basin.
} 
For trace metals and dioxins a substantial reduction of their sediment concentrations since the 80ies and 90ies is observed, but this is not the case for the PAHs. This is confirmed by emission trends of these contaminants.

\section{INTRODUCTION}

Sediments are archives of past and present anthropogenic activities located in the vicinity of an aquatic system. However, in some cases the contribution of long range pollutant transport should be taken into account. Direct wastewater discharges from industrial origin (point source) are the easiest traceable in sediments but pollutants associated with contaminated soils alongside the river border can also accumulate in the same sediments via rainwater run-off (diffuse source). On a local scale, unprotected waste dumping sites or stockpiles contaminate the soils around, while atmospheric deposition (vapor and aerosols) can pollute much vaster areas.

The Upper-Scheldt (see Figure 1; a more detailed description is given in the Methods and Materials section) is a transboundary river, having its source in the North of France and then flowing to Belgium (Flanders) and the Netherlands. The total length of river and estuary is $350 \mathrm{~km}$ while the length of the Upper-Scheldt between Oudenaarde and its source (Saint-Quentin) amounts to $165 \mathrm{~km}$. The environmental stress on the Upper-Scheldt river is very high due to important historical industrial activities such as coal mining, electricity production, steel and non-ferrous metals' smelters, textile manufacturing, .. and present activities such as textile manufacturing, glass production, steelworks, metal shredders, transformation industry, incinerators, chemical industry, ... The historical industrial activities in Northern France are the main cause of high contamination levels in the Upper-Scheldt river sediments. Most of the steel and non-ferrous metals' smelters are no longer active (e.g. Metaleurop at Noyelles-Godault at the Deûle river ceased their activities in 2003), but they discharged in the past high amounts of waste, especially metals, in the tributaries and canals of the Upper-Scheldt river creating highly contaminated sediments. In addition, mining activities have ceased since the 80's, but the extraction waste still pollutes soils, ground and river water (Denimal et al. 2001) ${ }^{1}$ by infiltration and by run-off, further increasing the contamination level of the sediments. High temperature processes related to the steel and non-ferrous metals' smelters, incinerators or metal shredders produced high amounts of organic pollutants such as PAHs, PCBs, PCDD/Fs and metals (Chagger et al., 2000; Meij and Winkel, 2007; Liu et al., 2009) 
${ }^{2-4}$. Deposition of these organic contaminants on the soils bordering the Upper-Scheldt river and its tributaries also contributed to the pollution of the sediments.

The Yser river (Figure 1) flows from France to West-Flanders (Belgium) and is thus also a transboundary river with a total length of about $60 \mathrm{~km}$. It is located about $50 \mathrm{~km}$ west of the UpperScheldt river but only $30 \mathrm{~km}$ from the Deûle river draining high amounts of contaminants to the Upper-Scheldt via the Spiere canal. The main difference with the Upper-Scheldt is that the Yser river has not been impacted by nearby industrial activities, neither in the past nor at present and that it is therefore used as a source of drinking water in Flanders. Since both rivers belong to separate river basins, no exchange of pollutants via the aquatic compartment is possible and only deposition processes may be in common. It is thus interesting to compare the contamination levels in the sediments in the Upper-Scheldt and the Yser rivers and to deduce the sources of that contamination. Moreover, a comparison with background levels is also presented. Contaminants that have been assessed are the following: the metals $\mathrm{Al}, \mathrm{Cd}, \mathrm{Cu}, \mathrm{Pb}$ and $\mathrm{Zn}$, the $17 \mathrm{PCDD} / \mathrm{Fs}$ and 4 dioxin-like PCBs congeners and the 16 USEPA PAH congeners: naphthalene (N), acenaphtylene (Acy), acenaphtene (Ace), fluorene $(\mathrm{F})$, phenanthrene $(\mathrm{P})$, anthracene $(\mathrm{A})$, fluoranthene $(\mathrm{Fl})$, pyrene (Pyr), benzo[a]anthracene $(\mathrm{BaA})$, chrysene + triphenylene (Chry), benzo[b]fluoranthene $(\mathrm{BbF})$, benzo[k]fluoranthene $(\mathrm{BkF})$, benzo[a]pyrene $(\mathrm{BaP})$, indeno[1,2,3-cd]pyrene (IdP), dibenz[ah]anthracene (DA), benzo[ghi]perylene (BPer).

\section{MATERIALS AND METHODS}

Sampling

Bottom sediment samples were collected in the rivers Upper Scheldt in October 2003 - eight stations between $\mathrm{km}=281$, Bassin Rond, and $\mathrm{km}=185$, Oudenaarde - and in the Yser in November 2005 - 10 stations between $\mathrm{km}=58$, la Cloche, and $\mathrm{km}=1$, Nieuwpoort (Figure 1) by a diver using a plexicore sampling tube. The surface sediment samples were homogenized, deepfrozen, lyophilized and ground in the laboratory.

The specific analytical procedures for determination of PCDD/Fs, dioxin-like PCBs, PAHs and trace metals are described into detail in the Supporting Information file. Below, a brief summary is given. 


\section{Chemical analysis of $P C D D / F$ s and dioxin-like $P C B S$}

About $20 \mathrm{~g}$ of sediment sub-sample was extracted with toluene by pressurized liquid extraction using a Dionex (USA) ASE-200 extractor. The extracts were spiked with labeled congeners. A clean-up step was performed in 2 steps: first with a multilayer silica/silver nitrate/alumina column and secondly with a carbon column.

PCDD/Fs and dioxin-like PCBs were analyzed by GC - high resolution MS (Hewlett Packard 6890 and Autospec Ultima of Waters).

\section{Analysis of PAHs}

Sediment samples were first spiked with deuterated internal standards. Then about $10 \mathrm{~g}$ were extracted with a hexane-acetone (50/50) mixture by pressurized liquid extraction using a Dionex (USA) ASE-200 extractor. Clean-up and isolation of PAHs were performed on a 3\% deactivated silica gel 60 column.

PAHs were analyzed using a Varian 3900 gas chromatograph equipped with a deactivated fusedsilica guard column of $5 \mathrm{~m}$ (Varian Inc.) and a fused-silica capillary column VF-5ms of $30 \mathrm{~m}$ (Varian Inc.). The gas chromatograph was coupled to an Ion Trap Saturn 2000 Mass Spectrometer (Charriau et al., 2009) ${ }^{5}$.

\section{Analysis of metals}

The extraction of trace metals from the sediment samples was performed in PTFE digestion bottles using the CEM Mars 5 microwave oven. To 0.1-0.2 g of lyophilized sediment sample $6 \mathrm{~mL}$ distilled $\mathrm{HNO}_{3}$ and $2 \mathrm{~mL} \mathrm{HCl}$ were added and the mixture was heated to $150{ }^{\circ} \mathrm{C}$.

Trace metal analysis was performed using a Sector Field High Resolution ICP-MS (Thermo Finnigan Element II). 


\section{RESULTS}

Recovery correction, confidence intervals and quality control

The PCDD/Fs, dioxin-like PCBs, PAHs trace metals concentrations in sediments from the Upper Scheldt river and the Yser river are shown in Table 1.

PCDD/Fs and dioxin-like PCBs were determined in the sediment after an extraction and clean-up procedure. To account for the loss of each congener during that sample treatment, each sediment sample was spiked with known amounts of marked $\left({ }^{13} \mathrm{C}\right)$ congeners. To account for the loss of the 16 USEPA-PAH congeners during extraction and clean-up, a recovery factor for each congener was assessed on a reference sediment material (NIST SRM 1944): it varied between 60\% (Acenaphtene) and $127 \%$ (Chrysene), but for 12 of the 16 PAHs, the range was much smaller (from 77 to $112 \%$ ). The recovery of the trace metals assessed on the CRM (LGC 6139) is close to 100\% for each metal and does not require any correction for the extraction step.

The uncertainties on the analyte concentrations in a sediment were estimated by repeated analysis of a CRM for PAHs and trace metals and of a homogenized and lyophilized bulk sediment (our own reference sediment) that we collected in the Scheldt river at $\mathrm{km}=92$ from the mouth for the PCDD/Fs and dioxin-like PCBs. The following uncertainties were observed: (1) on average $4.5 \%$ for the PAH congeners; (2) on average $16 \%$ for the PCDFs and $7 \%$ for $2,3,4,7,8-\mathrm{PeCDF}$ (the congener with the highest TEF value of PCDFs), on average 26\% for the PCDDs and 18\% for TCDD (the congener with the highest TEF value of PCDDs), on average $13 \%$ for dioxin-like PCBs and $12 \%$ for PCB-126 (the congener with the highest TEF value of PCBs) and (3) between 2.9 and $5.2 \%$ for the trace metals.

Control charts of procedural blanks and of CRMs (PAHs and trace metals) or our own reference sediment (PCDD/Fs and dioxin-like PCBs) were used as a quality control for the analyses.

\section{Longitudinal pollutant profiles in the Scheldt and Yser rivers}

The sediments in the Upper-Scheldt river are generally much more contaminated than those in the Yser, except for $\mathrm{Al}$ which is, however, not a pollutant and has a completely different behaviour and nature than trace metals. The anthropogenic impact on the Upper-Scheldt river ecosystem was and is much more diverse and intense than on that of the Yser river, that mainly deals with agricultural activities. In the past, mining activities, smelters and textile industries developed along the Upper 
Scheldt river, but after a decline in the seventies industrial activities were reaffected. Past and present anthropogenic activities heavily contaminated the Upper-Scheldt river (Denimal et al., 2001; Gao et al., 2006; Boughriet et al., 2007; Charriau et al., 2009) ${ }^{1,5-7}$.

$\mathrm{Cu}$ levels are the most comparable in the 2 rivers: $50 \%$ of the sediments in the Upper-Scheldt have lower analyte concentrations than the maximum level observed in the Yser. The relatively higher $\mathrm{Cu}$ levels in the Yser sediments are due to the natural concentration of this metal in the soil of the Yser Region (VMM, 2007) ${ }^{8}$. For all other pollutants we see that the majority of the sediments in the Upper-Scheldt river (from $57 \%$ for USEPA-PAHs to $100 \%$ for Cd, see Table 1) have higher pollutant levels than the maximum level in Yser sediments. The opposite is true for $\mathrm{Al}$, an element that is often used as a proxy for the fine inorganic sediment fraction: $80 \%$ of the sediments in the Yser show higher Al levels than the maximum level in the Upper-Scheldt.

The Upper-Scheldt river sediments at Lourches and Spiere-Helkijn show the highest contamination, except for PCDD/Fs and dioxin-like PCBs at the latter station. The peak at Spiere-Helkijn is probably due to historical pollution in that area. The Spiere canal (Belgium) - Canal de Roubaix (France) connects the Deule river to the Upper Scheldt. This canal is no longer in use for navigation since 1985; historically, it has transported a large amount of pollutants from the industries - wool manufacturing industries (Izac, 1985) ${ }^{9}$ and non-ferrous industry (e.g. Metaleurop) - in the North of France and municipal wastes from the agglomerations of Lille, Roubaix and Tourcoinq (VMM, $2007)^{8}$. Coal mining led to the development of an industrial site at Lourches, including smelters (e.g. USINOR), coke ovens and electricity plants. These industrial activities had a strong and negative impact on the environment in general and the Upper-Scheldt river in particular. In the Yser river the sediments at station 4 (Diksmuide) and station 6 (Lo-Reninge) are the most contaminated. A Spearman Rank Order correlation matrix (see Table S1 in Supplementary Material) including all our data shown in Table 1 was established. Except for Al, all p-values were below 0.05, indicating significant relationships and correlation coefficients at least 0.8 or higher (only those with PAH are somewhat lower). This information gives us new insight about the impact of industrial and agricultural activities on the contamination level of riverine sediments: although there is a large difference in magnitude of contamination, some common mechanism(s) may exist. For PAHs significant correlations were observed too, but with somewhat lower correlation coefficients. Al was not correlated with any of the other compounds as expected. 


\section{DISCUSSION}

$\underline{P A H S}$

The reference concentration for the 6 Borneff PAHs derived from low contaminated sediments in Flemish rivers amounts to $0.22 \mathrm{mg} \mathrm{kg}^{-1}$ (De Sadeleer et al., 2010) ${ }^{10}$. This value is comparable with the Background Concentration (BC) of the 16 USEPA-PAHs in North Sea sediments reported by OSPAR: $0.525 \mathrm{mg} \mathrm{kg}^{-1}$ for a sediment normalized to $2.5 \%$ organic carbon (OSPAR, 2005) ${ }^{11}$. In the Yser river sediments, two upstream stations (La Cloche and Poperinge) have PAH concentrations comparable to that $\mathrm{BC}$ value, while all other stations are between 2 to 8 times more enriched. In the Upper-Scheldt river, sediments are still more enriched in PAHs, with three stations exceeding by a factor more than 10 the $\mathrm{BC}$ value. In contrast to most other contaminants (e.g. trace metals, dioxins,..), the PAH concentrations did not show a decreasing trend with time. Charriau et al. $(2009)^{5}$ studied a depth profile of PAH in a sediment core $(25 \mathrm{~cm})$ at Helkijn $(\mathrm{km}=212)$. The sum of the 16 USEPA PAHs were comprised between 5.1 and $8.3 \mathrm{mg} \mathrm{kg}^{-1} \mathrm{dw}$, without any clear tendency with depth. Atmospheric PAH emissions (16 USEPA) for the whole Flemish Region were estimated by VMM (2008a) ${ }^{12}: 183$ tons in 1996, 182 tons in 2000 and 200 tons in 2008. The French Water Authority (Agence de 1'Eau Artois-Picardie) ${ }^{13}$ reported PAH concentrations for BaA, BaP, $\mathrm{BbF}, \mathrm{BPer}$ and $\mathrm{BkF}$ in sediments at stations Fresnes ( $\mathrm{km} \mathrm{253)}$ and Eswars ( $\mathrm{km} \mathrm{284.5).} \mathrm{Median}$ values for the period 1990-1999 (Table 2) were $4.7 \mathrm{mg} \mathrm{kg}^{-1}$ (Eswars) and $3.4 \mathrm{mg} / \mathrm{kg}$ (Fresnes), while in the period 2000-2007 these median values barely changed with values of $4.4 \mathrm{mg} \mathrm{kg}^{-1}$ (Eswars) and $4.1 \mathrm{mg} \mathrm{kg}^{-1}$ (Fresnes). Although the French Water Authority determined only $5 \mathrm{PAH}$ congeners, their sum of concentrations is yet an order of magnitude higher than the background concentration of OSPAR $(2005)^{11}$ for the sum of the 16 USEPA-PAH congeners. The evolution of the PAH concentrations observed in the Spiere river close to its confluence with the Upper-Scheldt at $\mathrm{km} 211$ (the Spiere river flows alongside the Spiere canal and is also heavily polluted) forms an exception. The mean annual 16 USEPA-PAH concentration amounts to $2.4 \mu \mathrm{g} \mathrm{L}^{-1}$ in 2000 , which is about six-folds higher than in $2009\left(0.42 \mu \mathrm{g} \mathrm{L}^{-1}\right.$ in 2009), but withdrawing three low molecular weight congeners (naphtalene, phenantrene and fluorene) the difference is reduced to a factor of 2 $\left(0.62 \mu \mathrm{g} \mathrm{L}^{-1}\right.$ versus $\left.0.29 \mu \mathrm{g} \mathrm{L}^{-1}\right)$. A reasonable explanation for the difference between the 2000 and 
2009 contamination levels is the putting into service of a new waste water treatment plant (WWTP) at Grimonpont in 2004. In fact, the total flow of the Spiere river is treated by the WWTP. Since 2004, the data collected by the French water agency (Agence de l'Eau Artois-Picardie) ${ }^{13}$ indicate a general improvement of the water quality: strong decrease of the chemical oxygen demand, of the biological oxygen demand and of phosphates, and increase of the dissolved oxygen concentration (from less than $20 \%$ to more than $80 \%$ of the saturation).

The major PAH congeners in the sediments of the Upper-Scheldt and Yser rivers are fluoranthene and pyrene (mass isomers with a molecular weight of 202 and 4 aromatic rings) representing respectively between $27-34 \%$ and $23-41 \%$ of the total PAH amount in the sediments of those rivers. Sources of PAH contamination in sediments (pyrolytic or petrogenic) can be investigated by studying the general fingerprint and by using several PAH diagnostic ratios. PAHs are subdivided in Low Molecular Weight (LMW) compounds, containing 2 to 3 aromatic rings, and High Molecular Weight (HMW) compounds, containing 4 to 6 aromatic rings. When the HMW compounds dominate (LMW/HMW ratio is inferior to 1), a pyrolytic origin is suggested and vice versa (De Luca et al., 2005) ${ }^{14}$. In both rivers, the LMW/HMW ratio is even beneath 0.5, except at SpiereHelkijn with a value of 0.6 , indicating a pyrolytic origin (Table 3). In addition of the LMW/HMW ratio, molecular ratios based on differences of thermodynamic stabilities between isomers of the same molecular mass have been frequently used to discriminate between PAH sources (Yunker et al., 2002) ${ }^{15}$. However, care must be taken when applying these ratios for source recognition, because in that case assumption is made that mass isomers have similar physical chemical properties and are subjected to degradation and dilution to the same extent during their transport to the sediment (Zhang et al., 2005) ${ }^{16}$. For example ratios involving LMW PAH compounds are less accurate than those of HMW compounds: the latter are less volatile and their ratios have thus a higher stability. In addition, PAHs can enter sediments via numerous sources, therefore isomer mass ratios are often studied simultaneously (multiple lines of evidence) (Yunker et al., 2002; Oros and Ross, 2004) ${ }^{15,17}$.

PAH source characterization is carried out using PAHs of molecular mass 178, 202, 228 and 276. Boundary values indicating differences in source type are based on Yunker et al. (2002) ${ }^{15}$ and references therein. The anthracene/(anthracene + phenanthrene) or $\mathrm{A} / 178$ ratio indicates a petrogenic origin when values are below 0.10 while values $>0.10$ are characteristic of combustion 
derived PAHs. The same is true for the benz[a]anthracene/(benz[a]anthracene + chrysene) or $\mathrm{BaA} / 228$ ratio although the boundaries are less clear: $<0.20$ suggests petrogenic origin and $>0.35$ combustion. For a fluoranthene/(fluoranthene + pyrene) or $\mathrm{Fl} / 202$ ratio below 0.40 a petrogenic origin is suggested while for values above 0.50 grass, wood or coal combustion is indicated. The indeno[1,2,3-cd]pyrene/(indeno[1,2,3-cd]pyrene + benzo[ghi]-perylene) or IdP/278 ratio $<0.20$ indicates a petrogenic origin and a value $>0.50$ grass, wood and coal combustion.

Zhang et al. $(2005)^{16}$ considers the HMW PAHs indeno[1,2,3-cd]pyrene and benzo-[ghi]perylene amongst the most reliable PAHs for source recognition in various media. This is in agreement with Yunker et al. (2002) ${ }^{15}$ who concluded that the 202 and 276 molecular weight ratios allow better interpretations because of higher differences in thermodynamic stabilities between the mass isomers. All our PAH diagnostic ratios (Table 3) indicate that the origin of the PAHs in the sediments of Yser and Upper-Scheldt is pyrolytic (combustion of biomass or coal). This is consistent with the data reported by Charriau et al. (2009) ${ }^{5}$ in the sediment core at Helkijn. The diagnostic ratios' profiles were very homogeneous with depth and also indicated a pyrolytic origin for the PAH congeners. In 2008, atmospheric PAH congener profiles that were measured in the neighborhood of a steel producer (Arcelor-Mittal, Ghent), yield similar PAH diagnostic ratios as those observed in the sediments, only the benz[a]anthracene/(benz[a]anthracene + chrysene) ratio was somewhat lower (Table 4).

\section{$\underline{\text { Trace metals }}$}

The reference trace metal concentrations observed by De Sadeleer et al. $(2010)^{10}$ in low contaminated sediments in Flemish rivers amount to: $0.4 \mathrm{mg} \mathrm{kg}^{-1}(\mathrm{Cd}), 4 \mathrm{mg} \mathrm{kg}^{-1}(\mathrm{~Pb}), 67 \mathrm{mg} \mathrm{kg}^{-1}$ $(\mathrm{Zn}), 8 \mathrm{mg} \mathrm{kg}^{-1}(\mathrm{Cu})$ which compare, except for $\mathrm{Pb}$, well with the Background Concentrations in North Sea sediments, normalized to $5 \% \mathrm{Al}$, reported by OSPAR (2005) ${ }^{11}: 0.2 \mathrm{mg} \mathrm{kg}^{-1}$ (Cd), $25 \mathrm{mg}$ $\mathrm{kg}^{-1}(\mathrm{~Pb}), 90 \mathrm{mg} \mathrm{kg}^{-1}(\mathrm{Zn}), 20 \mathrm{mg} \mathrm{kg}^{-1}(\mathrm{Cu})$. The trace metal concentrations in the Yser sediments do not exceed the highest of both norms by more than a factor two $(\mathrm{Cu}$ seems to be the most enhanced of all metals), indicating that they are only slightly contaminated by the four selected metals. On the contrary, the Upper-Scheldt river sediments are heavily contaminated by those metals. Especially $\mathrm{Cd}$ and $\mathrm{Pb}$ levels exceed at some of the sampling stations the highest of both 
norms by more than an order of magnitude. The trace metal concentrations in the sediments of Belgium riverine stations (Oudenaarde, Spiere-Helkijn and Antoing) can be compared with historical values reported for dredged sediment landfills by Vandecasteele et al. (2002) ${ }^{18}$ along the same stretch of the Upper-Scheldt. For several decades, periodical dredging of river sediments has been necessary to allow for shipping traffic on the river Scheldt. Since the 90ies dredged sediments are disposed in confined disposal sites, but previously the dredged sediments were simply stored on the river banks or on the shores of the alluvial plains without concern for the impact of these contaminated sediments on the environment including surface and ground water, fauna and flora. The average concentrations of $\mathrm{Cd}\left(8.7 \mathrm{mg} \mathrm{kg}^{-1}\right), \mathrm{Cu}\left(84 \mathrm{mg} \mathrm{kg}^{-1}\right), \mathrm{Pb}\left(192 \mathrm{mg} \mathrm{kg}^{-1}\right)$ and $\mathrm{Zn}(1,100$ $\mathrm{mg} \mathrm{kg}^{-1}$ ) in the dredged sediment landfills (Vandecasteele et al., 2002) ${ }^{18}$ are all above the values observed in the sediments of the Oudenaarde, Spiere-Helkijn (here only slightly) and Antoing stations (see Table 1). This confirms that historical contamination levels in the Upper-Scheldt river (the sediments in the landfills were mainly dredged in the period 1945-1990) were much higher than today. Atmospheric trace metal emissions for the whole Flanders Region decreased between 2000 and 2008 with a factor 2 (7 for the period 1996-2008) for Cd, a factor 2.8 (8 for the period 19962008) for $\mathrm{Pb}$, a factor 2.1 (2.6 for the period 1996-2008) for $\mathrm{Zn}$ and not for $\mathrm{Cu}$. Between 2000 and 2009 (VMM, website data) ${ }^{19}$, the trace metal concentrations in the Spiere river (see also for PAHs here above) decreased by a factor of 7 for $\mathrm{Cd}, 1.6$ for $\mathrm{Pb}$ and 3.5 for $\mathrm{Zn}$. The decrease for $\mathrm{Cu}$ was much stronger (a factor of 18) but reduced to only a factor of 2 between 2004 and 2009. The smaller reduction after 2004 is probably an effect of the WWTP put in operation for the Spiere river in 2004 and on the rehabilitation of several stock piles of chromium residues and phosphogypsum on derelict land along the Spiere river.

In the sediments of the Scheldt stations in France, also high trace metal levels were observed. A study of trace metal concentrations in the sediments of the Deule river, impacted by the Metaleurop smelter, revealed $\mathrm{Pb}$ levels between 26.8 - 10,000 $\mathrm{mg} \mathrm{kg}^{-1}$, Zn levels between $150-13,000 \mathrm{mg} \mathrm{kg}^{-1}$ and Cd levels between $1.15-1,400 \mathrm{mg} \mathrm{kg}^{-1}$ (Boughriet et al., 2007) ${ }^{7}$. In this Northern France Region, several other smelters (e.g. USINOR close to the station of Lourches) were active in the past contaminating directly the sediments in the Upper-Scheldt or indirectly via for example the Deule river which is connected to the Upper-Scheldt river via the Spiere canal. In addition, the stock piles of extracted waste at several sites along the Upper-Scheldt in Northern France are also 
contributing to the metal concentrations in the Upper-Scheldt sediments. In the sediments at stations Fresnes (km 253) and Eswars (km 284.5) a decrease in the trace metal levels between 1980-1989 and the most recent decade 2000-2007 is observed, except for copper (Table 2). The median values for $\mathrm{Cd}, \mathrm{Pb}$ and $\mathrm{Zn}$ were between 2 and 3 times lower in the period 2000-2007 compared to 19801989. While $\mathrm{Cu}$ concentrations were the highest in the period 1990-1999 they reached their 19801989 level again in the most recent period. This is in agreement with trends observed for atmospheric $\mathrm{Cu}$ emissions in Flanders (VMM, 2008a) ${ }^{12}$.

Since the sediments in the Upper-Scheldt river are heavily contaminated by trace metals, it is important to know more about their lability and mobility. At Helkijn (km 212), the upper sediment is gradually changing from a sub-oxic to an anoxic system. In the pore waters of that sub-oxic sediment zone increased concentrations of $\mathrm{Fe}, \mathrm{Mn}, \mathrm{Co}$ and $\mathrm{Cu}$ were observed using Diffusive Gradient in Thin Film (DGT) and Diffusive Equilibrium in Thin Film (DET) techniques by Gao et al. $(2006)^{6}$. This is corroborated by a partial re-oxydation of AVS (Acid Volatile Sulphides) near the water-sediment interface, a solubilization of the trace metals and an increased toxicity (Lesven et al., 2008) $)^{20}$. Both studies allowed a ranking of the metals according to their mobility and hence bioavailability: $\mathrm{Cu}>\mathrm{Cd}>\mathrm{Pb}$. The metals released from upstream sediment deposits may reaccumulate in downstream sediment deposits.

\section{$\underline{P C D D / F \text { values }}$}

Although no historical data of dioxins in the sediments of Upper-Scheldt and Yser rivers exist, the trend is that maximum emissions occurred some time ago. Atmospheric PCDD/F emissions estimated for the whole Flemish Region by VMM (2008a) ${ }^{12}$ amount to 287 g-TEQ for the year 1996, 57 g-TEQ for 2000 and 45 g-TEQ for 2008. The dioxin-like PCB to PCDD/F ratios vary between 33 and 89\% in Upper-Scheldt sediments and 22 to $39 \%$ in those of the Yser.

The PCDD/F congener profiles in the sediments of the Yser and the Upper-Scheldt rivers (4 stations are randomly selected) are shown in Figure 2. These fingerprints are strongly dominated by the OCDD congener, which represents between 73 and $85 \%$ of the total PCDD/F concentration (pg/gsediment) in the sediments of the Upper-Scheldt respectively between 62 and $76 \%$ in those of the Yser river. We can compare these congener patterns observed in the sediments with those from deposition measurements in the neighbourhood. The closest monitoring station of atmospheric 
deposition is Menen, located almost in the middle between the Yser and Upper-Scheldt rivers and at a nearest distance of about $20 \mathrm{~km}$ from each. In these deposition samples, OCDD is again the dominant congener (VMM, 2008b) ${ }^{21}$ with 55 to $66 \%$ of the total PCDD/F amount (Figure 3). The congener profiles in the sediments and in the atmospheric deposition samples are very similar, with OCDD by far the most ubiquitous followed by HpCDD. In the monitoring stations Gistel (North of the Yser) and Veurne (West of the Yser), again similar congener dioxin profiles were observed in the deposition material (Figure 3). While combustion seems to be the major source of these PCDD/Fs in the atmospheric deposition and sediments, Baker and Hites $(2000)^{22}$ suggest another important source. They found that emission and deposition values balance well for most congeners except for OCDD, which seems to have about 40 times more deposition than emission. There is also a smaller but significant imbalance for HpCDD which seems to have about 6 times more deposition than emissions. Looking to an explanation, they suggest that some of the abundant Pentachlorophenol (PCP) in the environment can be converted in the atmosphere to OCDD, and to a lesser extent to HpCDD, and that this is the primary source of OCDD and HpCDD in environmental sinks. In fact, the vapour pressure of PCP is high enough for volatilization and consequently to disperse it widely in the environment. Hence, besides combustion processes conversion of PCP into OCDD and HpCDD in the atmosphere can not be ruled out as a potential source of PCDD/Fs in our deposition and sediment samples.

Past and present anthropogenic activities heavily contaminated the sediments of the UpperScheldt river, much more than those in the Yser river although for most of the pollutants studied in this rural river, Background Concentrations are also several times exceeded requiring for the production of drinking water a severe treatment of the river water. Only the highest levels of PAHs, PCDD/Fs, dioxin-like PCBs and copper in the Yser sediments reach the lower levels in the UpperScheldt sediments. Despite the differences in contamination level, a very good correlation between all pollutants in Upper-Scheldt and Yser rivers sediment samples was observed. This may suggest that some common mechanism and/or source(s) are causing that contamination. Based on diagnostic ratios established for PAH congeners with the same isomeric mass, the PAH contamination in both rivers should be combustion of biomass or coal. For PCDD/Fs a deposition mechanism can explain the contamination of the sediments. The source(s) is (are) either combustion and/or atmospheric 
OCDD formation reactions from pentachlorophenol. Contamination of PAHs and PCDD/Fs in both river sediments are thus from atmospheric origin. For trace metals the contamination sources are more diverse. The high contamination in the Upper-Scheldt sediments is caused via direct wastewater discharges in the past and nowadays via stock piles of solid waste (Northern France), historical dumping sites of dredged sediments alongside the river border (Flanders) and run-off from soils contaminated by atmospheric deposition of trace metals. Higher $\mathrm{Cu}$ levels in Yser sediments are due to natural soil enriched in that element.

For trace metals (except for $\mathrm{Cu}$ ) a substantial reduction of their sediment concentrations since the 80ies and 90ies is observed, but this is not the case for the PAH sediment concentrations. This is confirmed by emission trends (aquatic and atmospheric) of these contaminants, by comparison with dredged sediment landfills (Upper-Scheldt river Belgium) and with historical monitoring results by the French water agency (Agence de l'eau) in the Upper-Scheldt river (France). For PCDD/Fs this is probably also the case but there are no data available to confirm that.

\section{ACKNOWLEDGEMENT}

This work was financed by the Belgian Science Policy (contract DWTC235 TIMOTHY, Interuniversity Attraction Poles P6/13) and an EU-INTERREGIII project (STARDUST). We are grateful to l'Agence de l'eau Artois-Picardie and VMM for free access to their databases.

Supporting Material: a detailed description is given of the Materials and Methods that we used as wel as a Correlation Table between all variables measured in the sediment samples.

\section{REFERENCES TO ARRANGE!!!!}

1. Denimal, S.; Barbecot, F.; Dever, L.; Tribovillard, N.; Meilliez, F. Chemical and isotopic tracing of underground water in relation with leaching of mine spoils, Nord-Pas-de-Calais Coal Basin (France). Bulletin de la Société Géologique de France 2001, 172, 111-120.

2. Chagger, H. K.; Jones, J. M.; Pourkashanian, M.; Williams, A. The formation of VOC, PAH and dioxins during incineration. Process Safety Environ. Protect. 2000, 78, 53-59. 
3. Meij, R.; Winkel, H. T. The emissions of heavy metals and persistent organic pollutants from modern coal-fired power stations. Atmos. Environ. 2007, 41, 9262-9272.

4. Liu, G. R.; Zheng, M. H.; Liu, W. B.; Wang, C. Z.; Zhang, B.; Gao, L. R.; Su, G. J.; Xiao, K.; Lv

P. Atmospheric Emission of PCDD/Fs, PCBs, Hexachlorobenzene, and Pentachlorobenzene from the Coking Industry. Environ. Sci. Technol. 2009, 43, 9196-9201.

5. Charriau, A.; Bodineau, L.; Ouddane, B.; Fischer, J-C. Polycyclic Aromatic Hydrocarbons and nalkanes in sediments of the Upper Scheldt River Basin: contamination levels and source apportionment. J. Environ. Monit. 2009, 11, 1086-1093.

6. Gao, Y.; Leermakers, M.; Gabelle, C.; Divis, P.; Billon, G.; Ouddane, B.; Fischer, J-C.; Wartel, M.; Baeyens, W. High Resolution Profiles of Trace Metals in the Porewaters of Riverine Sediment Assessed by DET and DGT. Sci. Tot. Environ. 2006, 362, 266-277.

7. Boughriet, A.; Proix, N.; Billon, G.; Recourt, P.; Ouddane, B. Environmental impacts of heavy metal discharges from a smelter in Deule-canal sediments (Northern France): Concentration levels and chemical fractionation. Wat. Air Soil Poll. 2007, 180, 83-95.

8. VMM (Flemish Environmental Agency). Jaarverslag water 2007 (Annual Report Water 2007). 2007, 123 pp.

9. Izac, A. M. N. Conflicts of interest in international environmental policies: the case of transfrontier pollution in Europe. Int. J. Environ. Stud. 1985, 26, 33 - 42.

10. De Saedeleer, V.; Cappuyns, V.; De Cooman, W.; Swennen, R. Influence of major elements on heavy metal composition of river sediments. Geologica Belgica 2010, 13, 257-268.

11. OSPAR (Oslo and Paris Conventions). OSPAR Convention for the protection of the Marine Environment of the North-East Atlantic. Agreement on Background Concentrations for Contaminants in Seawater, Biota and Sediment (OSPAR Agreement 2005-6). Replaces OSPAR Agreement 1997-14. 2005, 4 pp. http://www.ospar.org/documents/dbase/decrecs/agreements/0506e_agreement $\% 20 \mathrm{Bcs}$. doc.

12. VMM (Flemish Environmental Agency). Lozingen in de lucht 1990-2008 (Atmospheric emisions 1990-2008). 2008a, 244 pp.

13. Agence de l'eau Artois-Picardie (Water Agency of Artois-Picardie), http://www.eau-artoispicardie.fr/ 
14. De Luca, G.; Furesi, A.; Micera, G.; Panzanelli, A.; Piu, P. C.; Pilo, M. I.; Spano N., Sanna, G. Nature, distribution and origin of polycyclic aromatic hydrocarbons (PAHs) in the sediments of Olbia harbor (Northern Sardinia, Italy). Mar. Pollut. Bull. 2005, 50, 1223-1232.

15. Yunker, M. B.; Macdonald, R. W.; Vingarzan, R.; Mitchell, R. H.; Goyette D.; Sylvestre, S. PAHs in the Fraser River basin: A critical appraisal of PAH ratios as indicators of PAH source and composition. Org. Geochem. 2002, 33, 489-515.

16. Zhang, X. L.; Tao, S.; Liu, W. X.; Yang, Y.; Zuo Q.; Liu, S. Z. Source diagnostics of polycyclic aromatic hydrocarbons based on species ratios: A multimedia approach. Environ. Sci. Technol. 2005, 39, 9109-9114.

17. Oros, D. R.; Ross, J. R. M. Polycyclic aromatic hydrocarbons in San Francisco Estuary sediments. Mar. Chem. 2004, 86, 169-184.

18. Vandecasteele, B.; De Vos, B.; Tack, F. M.G. Heavy metal contents in surface soils along the Upper Scheldt river (Belgium) affected by historical upland disposal of dredged materials. Sci Tot Environ. 2002, 290, 1-14.

19. VMM (Flemish Environmental Agency), http://www.vmm.be/

20. Lesven, L.; Gao, Y.; Billon, G.; Leermakers, M.; Ouddane, B.; Fischer, J-C.; Baeyens, W. Early diagenetic processes aspects controlling the mobility of dissolved trace metals in three riverine sediment columns. Sci. Tot. Environ. 2008, 407, 447-459.

21. VMM (Flemish Environmental Agency). Analyses van dioxine- en PCB126- deposities in Vlaanderen in de periode mei 2007-april 2008 (Analyses of dioxin and PCB126 depositions in Flanders in the period May 2007 to April 2008). 2008b, 167 pp (part1) and 150 pp (part2).

22. Baker, J. I.; Hites, R. A. Is Combustion the Major Source of Polychlorinated Dibenzo-p-dioxins and Dibenzofurans to the Environment? A Mass Balance Investigation. Environ. Sci. Technol. 2000, 34, 2879-2886. 